\title{
Occurrence and differentiation of Arnoserido-Scleranthetum (Chouard 1925) in the Południowopodlaska Lowland
}

\author{
Zofia Rzymowska*, Teresa Skrajna, Janina Skrzyczyńska \\ Department of Agricultural Ecology, Siedlce University of Natural Sciences and Humanities, B. Prusa 14, 08-110 Siedlce, Poland
}

\begin{abstract}
The paper presents Arnoserido-Scleranthetum phytocoenoses at the eastern and north-eastern peripheries of their occurrence range and the results of a field study conducted in the Południowopolska Lowland in 1990-2010. The investigations were based on phytosociological relevés made by the Braun-Blanquet method.

The greatest numbers of localities of the analyzed association were found in the mesoregions located in the south-western part of the Południowopolska Lowland, i.e. the Kałuszyn Upland, Węgrów Lowering, Żelechów Upland, the south-western part of the Łuków Plain, and the southern part of the Siedlce Upland. Fewer patches of this association were reported from the eastern and north-eastern part of the Południowopolska Lowland, in particular from the Podlasie Gorge of Bug. With the exception of the latter one, in all the mesoregions the patches of the analyzed association exhibited internal variability reflecting the diversity of habitat moisture conditions, which was manifested by the occurrence of hygrophilous species in the analyzed phytocoenoses. They comprised patches of Arnoserido-Scleranthetum with Illecebrum verticillatum, which are regarded as threatened with extinction in Poland and Europe. The phytocoenoses of Arnoserido-Scleranthetum with the dominance of Anthoxanthum aristatum are particularly noteworthy as a reflection of degenerative changes caused by the mass occurrence of this expansive species.
\end{abstract}

Keywords: Arnoseris minima; acidophilic habitats; agrocoenoses; winter cereals; cereal communities; systematic group value

\section{Introduction}

The Arnoserido-Scleranthetum association, characterized by a sub-Atlantic character, occurs in an impoverished form in the western and central part of in Poland [1]. It occupies the poorest habitats with sandy acidic soils with a $\mathrm{pH}$ of 4.0-5.0. Arnoseris minima is a characteristic species serving a diagnostic function. In turn, Spergula morisonii, Veronica dillenii, Anthoxanthum aristatum, and Teesdaela nudicaulis are differential species occurring with varied frequency across Poland. The association tends to retreat from the area of Poland [2-7] and Europe [8-13]. The abandonment of land management on the poorest soils (land fallowing and afforestation) and changing habitat conditions through increased nutrient inputs pose a threat to the phytocoenoses of the association. The Arnoserido-Scleranthetum localities in the Południowopolska Lowland, in particular its north-eastern peripheries, are the easternmost and northernmost localities in the occurrence range of this retreating association.

*Corresponding author. Email: zofia.rzymowska@uph.edu.pl

Handling Editor: Elżbieta Weryszko-Chmielewska
The aim of the study is to analyze the Arnoserido-Scleranthetum phytocoenoses and assess the frequency of their occurrence in the mesoregions of the Południowopolska Lowland.

\section{Material and methods}

The field study involved analysis of phytosociological relevés made by the Braun-Blanquet method [14]. In total, over 2000 phytosociological relevés were taken in cereal-growing fields, including 262 defined as Arnoserido-Scleranthetum communities. Phytosociological classification was accepted according to Matuszkiewicz [1]. The nomenclature of species follows Mirek et al. [15]. The observations were carried out in 1990-2010 in the area of the Południowopolska Lowland macroregion. The investigations were conducted in 6 mesoregions, i.e. the Kałuszyn Upland, Węgrów Lowering, Siedlce Upland, Łuków Plain, Podlasie Gorge of Bug, and the eastern part of the Żelechów Upland. The total study area covered approximately $9000 \mathrm{~km}^{2}$ (Tab. 1). The study area comprises a large proportion of light sandy soils (a poor rye complex and a very poor rye complex), particularly in the Podlasie 
Gorge of Bug and Kałuszyn Upland. The Południowopolska Lowland is a typical agricultural macroregion with a high proportion of extensive farms, producing mostly for their own needs.

Tab. 1 Surface area of the investigated mesoregions.

\begin{tabular}{lc} 
Mesoregion & Area $\left(\mathbf{k m}^{2}\right)$ \\
\hline Kałuszyn Upland & 818 \\
Węgrów Lowering & 578 \\
Siedlce Upland & 2502 \\
Euków Plain & 2566 \\
Podlasie Gorge of Bug & 673 \\
Żelechów Upland & 1844 \\
Total & 8981 \\
\hline
\end{tabular}

The analysis of the distribution and frequency of the occurrence of Arnoserido-Scleranthetum phytocoenoses was based on the number of localities = locations and the proportion of association patches in potentially suitable habitats (on light acidic soils). The frequency was expressed in a 3-point scale: 1 - species covering over $60 \%$; 2 - species covering from 40 to $60 \%$; and 3 - species covering below $40 \%$ of the species-specific habitats. Constancy and cover factors were calculated for each species presented in the table [14]. In order to compare the analyzed phytocoenoses in the mesoregions in question, the systematic group value, illustrating the share of characteristic and differential species in these communities, was calculated [16]: $D=G \times S / 100$, where: $S$ - mean constancy of the group, $G$ - collective share of the group.

These parameters were calculated according to the following equations: $S=(g / z \times n) \times 100$ and $G=g / t \times 100$, where: $z$-number of species in the group, $n$ - total number of relevés in the association table, $g$ - sum of records of species from the particular groups in the table, $t$ - sum of records of all species in the table.

The systematic group value was calculated twice taking into account the share of Scleranthus annuus in the group of characteristic and differential species $\left(D_{1}\right)$ and disregarding the species $\left(D_{2}\right)$ due to its low diagnostic value caused by its frequent occurrence in other phytocoenoses in similar habitats.

\section{Results}

\section{Distribution and frequency of occurrence of} Arnoserido-Scleranthetum patches

The phytocoenoses of the analyzed association were noted most frequently in the Kałuszyn Upland, where the greatest density of patches, exceeding $60 \%$, was found on light and acidic soils in the individual localities.
A lower density of localities (40-60\%) was found in the Węgrów Lowering area, where nutrient-rich soils prevail. Similar frequency of the patches of the analyzed association was reported from the Żelechów Upland, the south-western part of the Łuków Plain, and the southern part of the Siedlce Upland.

In contrast, no phytocoenoses studied were found in the northern part of the Siedlce Upland due to the absence of habitats suitable for Arnoserido-Scleranthetum. This region comprises the largest proportion of the most fertile soils of the Południowopolska Lowland. Arnoserido-Scleranthetum patches were seldom observed in the area of the Podlasie Gorge of Bug as well. A higher share of patches of the associations in question was only reported in Mielnik commune. In the other parts of the Podlasie Gorge of Bug area, small insular localities of the association, exhibiting no temporal and spatial continuity, were only found.

\section{Analysis of the diversity of the composition and structure of the phytocoenoses of the analyzed associations}

In the Południowopolska Lowland, Arnoserido-Scleranthetum patches occupy different habitats in terms of moisture. This was reflected in the differences in the composition and structure of the analyzed communities. Typical and wet variants were distinguished. This diversity was observed in the entire study area with the exception of the Podlasie Gorge of Bug.

Systematics of the distinguished association Arnoserido-Scleranthetum Class: Stellarietea mediae Tx., Lohm. et Prsg. 1950

Order: Centauretalia cyani R. Tx. 1950

Alliance: Aperion spicae-venti R. Tx. et J. Tx. 1960

Association: Arnoserido-Sclerathetum (Edouard 1925)

R. Tx. 1937

1 typical variant

- typical subvariant

- subvariant with Anthoxanthum aristatum

2 variant form with hygrophilous species

- subvariant with Illecebrum verticillatum

- subvariant with Bidens tripartita

- subvariant with Juncus bufonius

- subvariant with Polygonum hydropiper

\section{Typical Arnoserido-Scleranthetum variant}

Communities with the greatest species richness were noted in the Kałuszyn Upland (a mesoregion located in the western part of the macroregion), where the average number of species per relevé was 13.4 (Tab. 2). Phytocoenoses developing in the area were characterized by the highest share of Arnoseris minima. High frequency and substantial cover rates were found in the patches of the analyzed association for the differential species Teesdalea nudicaulis and Anthoxanthum aristatum as well as, although less frequently, for Veronica dillenii, Spergula morisonii, and Holcus mollis. Similarly, Scleranthus annuus was characterized by a large share in the phytocoenoses of all the mesoregions.

Floristically poorer typical Arnoserido-Scleranthetum patches were found in the mesoregions located east of the Kałuszyn Upland, i.e. in the Węgrów Lowering, Siedlce Upland, Łuków Plain, and Żelechów Upland, where the average 
Tab. 2 Arnoserido-Scleranthetum (Chouard 1925) typicum variant in the Południowopodlaska Lowland.

\begin{tabular}{|c|c|c|c|c|c|c|c|c|c|c|c|c|c|c|}
\hline \multirow{2}{*}{$\frac{\text { Mesoregion }}{\text { Number of records }}$} & \multicolumn{4}{|c|}{ Kałuszyn Upland } & \multicolumn{2}{|c|}{$\begin{array}{l}\text { Węgrów } \\
\text { Lowering }\end{array}$} & \multicolumn{2}{|c|}{$\begin{array}{l}\text { Żelechów } \\
\text { Upland }\end{array}$} & \multicolumn{2}{|c|}{ Siedlce Upland } & \multicolumn{2}{|c|}{ Łuków Plain } & \multicolumn{2}{|c|}{$\begin{array}{c}\text { Podlasie } \\
\text { Gorge of Bug }\end{array}$} \\
\hline & \multicolumn{2}{|c|}{30} & \multicolumn{2}{|c|}{10} & \multicolumn{2}{|c|}{46} & \multicolumn{2}{|c|}{32} & \multicolumn{2}{|c|}{17} & \multicolumn{2}{|c|}{35} & \multicolumn{2}{|c|}{10} \\
\hline Number of species & \multicolumn{2}{|c|}{62} & \multicolumn{2}{|c|}{32} & \multicolumn{2}{|c|}{73} & \multicolumn{2}{|c|}{49} & \multicolumn{2}{|c|}{51} & & & & \\
\hline $\begin{array}{l}\text { Mean number of weed } \\
\text { species }\end{array}$ & & 3.4 & & .0 & & & & & & & & & & \\
\hline Subvariant & & ical & $\begin{array}{l}\text { Antho } \\
\text { ari }\end{array}$ & $\begin{array}{l}\text { th } \\
\text { anthum } \\
\text { atum }\end{array}$ & & & & & & & & & & \\
\hline Column No. & & & & 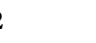 & & & & & & & & & & \\
\hline & $S$ & D & $S$ & D & $S$ & D & $S$ & D & $S$ & D & $S$ & D & $S$ & D \\
\hline I. Ch. D. Arnoserido- & canth & & & & & & & & & & & & & \\
\hline Arnoseris minima & $\mathrm{V}$ & 1192 & $\mathrm{~V}$ & 595 & $\mathrm{~V}$ & 573 & $\mathrm{~V}$ & 941 & IV & 159 & $\mathrm{~V}$ & 600 & $\mathrm{~V}$ & 385 \\
\hline Scleranthus anпuиs & $\mathrm{V}$ & 667 & III & 90 & $\mathrm{~V}$ & 700 & $\mathrm{~V}$ & 609 & $\mathrm{~V}$ & 262 & $\mathrm{~V}$ & 754 & $\mathrm{~V}$ & 500 \\
\hline Anthoxanthum aristatum & III & 163 & $\mathrm{~V}$ & 3250 & II & 48 & I & 66 & III & 1485 & I & 196 & & \\
\hline Veronica dillenii & II & 83 & I & 20 & II & 70 & II & 34 & III & 59 & I & 3 & I & 40 \\
\hline Teesdalea nudicaulis & III & 282 & II & 40 & I & 35 & I & 3 & I & 30 & I & 14 & & \\
\hline Holcus mollis & I & 87 & II & 110 & I & 4 & III & 78 & II & 295 & I & 20 & & \\
\hline Spergula morisonii & II & 63 & III & 50 & I & 4 & & & I & 12 & I & 3 & & \\
\hline II. Ch. Aperion spicae & $t i t, C$ & taurea & lia cya & & & & & & & & & & & \\
\hline Apera spica-venti & IV & 190 & III & 50 & IV & 283 & III & 133 & $\mathrm{~V}$ & 241 & IV & 184 & III & 90 \\
\hline Anthemis arvensis & III & 252 & III & 80 & IV & 229 & $\mathrm{~V}$ & 491 & II & 53 & IV & 331 & $\mathrm{~V}$ & 665 \\
\hline Centaurea cyanus & IV & 145 & II & 40 & III & 151 & III & 50 & I & 0 & III & 57 & IV & 245 \\
\hline Rhinanthus serotinus & I & 7 & & & I & 24 & II & 534 & I & 12 & I & 46 & & \\
\hline Vicia angustifolia & & & & & I & 9 & $\mathrm{I}$ & 9 & II & 35 & II & 29 & I & 60 \\
\hline III. Ch. Stellarietea $\mathrm{m}$ & & & & & & & & & & & & & & \\
\hline Viola arvensis & IV & 77 & III & 60 & IV & 78 & III & 44 & IV & 88 & IV & 74 & $\mathrm{~V}$ & 90 \\
\hline Fallopia convolvulus & IV & 90 & IV & 70 & IV & 91 & III & 72 & II & 53 & I & 14 & II & 80 \\
\hline Spergula arvensis & II & 60 & II & 70 & IV & 202 & III & 88 & I & 18 & III & 147 & IV & 275 \\
\hline Conyza canadensis & I & 7 & & & II & 52 & III & 63 & II & 23 & III & 141 & IV & 200 \\
\hline Raphanus raphanistrum & III & 50 & I & 10 & I & 26 & I & 13 & II & 18 & $\mathrm{I}$ & 11 & I & 20 \\
\hline Chenopodium album & II & 23 & I & 20 & I & 15 & I & 6 & I & 6 & I & 11 & I & 10 \\
\hline Digitaria ischaemum & I & 17 & I & 0 & I & 13 & I & 9 & II & 18 & I & 31 & I & 375 \\
\hline Setaria pumila & I & 7 & I & 10 & I & 88 & I & 16 & & & I & 14 & II & 245 \\
\hline Myosotis arvensis & I & 3 & & & I & 22 & I & 3 & & & I & 6 & II & 30 \\
\hline Setaria viridis & & & & & I & 15 & & & & & & & II & 70 \\
\hline IV. Accompanying sp & & & & & & & & & & & & & & \\
\hline Rumex acetosella & IV & 137 & II & 40 & IV & 332 & $\mathrm{~V}$ & 347 & III & 668 & $\mathrm{~V}$ & 430 & IV & 1135 \\
\hline Achillea millefolium & III & 53 & IV & 70 & I & 13 & I & 3 & I & 12 & & & I & 10 \\
\hline Elymus repens & II & 88 & III & 50 & I & 39 & I & 44 & III & 203 & I & 11 & I & 60 \\
\hline Equisetum arvense & II & 37 & I & 10 & I & 26 & I & 13 & II & 126 & II & 29 & III & 100 \\
\hline Agrostis stolonifera & & & & & I & 61 & II & 102 & I & 0 & I & 26 & III & 100 \\
\hline Convolvulus arvensis & II & 78 & II & 30 & I & 7 & I & 3 & I & 18 & II & 73 & I & 20 \\
\hline Allium vineale & I & 20 & II & 30 & I & 0 & I & 6 & & & I & 3 & & \\
\hline Holcus lanatus & I & 10 & II & 30 & II & 171 & I & 6 & I & 6 & & & & \\
\hline Equisetum sylvaticum & I & 3 & I & 10 & I & 13 & & & II & 144 & & & & \\
\hline Galeopsis bifida & & & & & I & 4 & I & 3 & I & 18 & & & II & 30 \\
\hline Trifolium arvense & & & & & I & 2 & & & II & 53 & & & & \\
\hline Trifolium repens & & & & & II & 171 & I & 3 & & & & & & \\
\hline
\end{tabular}

Sporadic species: II - Arabidopsis thaliana 1, 3, 4, 5, 7; Vicia villosa 1, 3, 4, 6, 7; Agrostemma githago 1, 3, 4, 6, 7; Vicia hirsuta 1, 4, 6, 7; Vicia tetrasperma 1, 6; Veronica triphyllos 3, 5; Vicia sativa 5; Hypochoeris glabra 5; Matricaria maritima subsp. inodora 6; III - Polygonum aviculare 1,2,3,5,6; Galeopsis tetrahit 1,2,3; Stellaria media 1, 3, 5; Capsella bursa-pastoris 1, 3; Crepis tectorum 1, 6; Polygonum lapathifolium subsp. pallidum 3, 4; Oxalis fontana 5, 6; IV - Galeopsis ladanum 1,3, 4, 5, 6; Corynephorus canescens $1,3,4,5,6 ;$ Knautia arvensis $1,3,4,5,7 ;$ Veronica arvensis $1,3,4,6,7 ;$ Polygonum lapathifolium subsp. pallidum 3,$4 ;$ Oxalis fontana 5, 6; IV - Galeopsis ladanum 1, 3, 4, 5, 6; Corynephorus canescens $1,3,4,5,6 ;$ Knautia arvensis 1, 3, 4, 5, 7; Veronica arvensis 1, 3, 4, 6,
Erodium cicutarium 1, 3, 4, 6, 7; Cirsium arvense 1, 2, 3,5; Myosotis stricta 3, 4, 5, 6; Cerastium holosteoides 1, 3, 4; Poa annua 1,3, 4; Spergularia rubra 1,3, 4; Polygonum persicaria 1, 3, 6; Erophila verna 1, 4, 6; Hypochoeris radicata 3, 5, 6; Melandrium album 3, 5, 7; Medicago falcata 1, 2; Linaria vulgaris 1,2; Veronica verna 1,3; Polygonum hydropiper 1, 3; Cerastium semidecandrum 1, 4; Sedum maximum 1, 5; Hieracium pilosella 1, 6; Artemisia campestris 1, 6; Hypericum perforatum 1, 7; Avena strigosa 3, 6; Artemisia vulgaris 3, 6; Arenaria serpyllifolia 3, 6; Daucus carota 3, 7; Festuca ovina 4, 5; Jasione montana 4, 6; Filago minima 5, 6; Taraxacum officinale 1; Artemisia absinthium 1; Gypsophila muralis 1; Bidens tripartita 1; Lepidium campestre 1; Stellaria graminea 1; Nardus stricta 1; Cichorium intybus 2; Plantago lanceolata 2; Anthoxanthum odoratum 3; Polygonum lapathifolium subsp. lapathifolium 3; Leontodon autumnalis 3; Viola tricolor 3; Mentha arvensis 3; Ranunculus repens 3; Anthoceros punctatus 3; Phleum pratense 3; Centaurea scabiosa 3; Agrostis vulgaris 5; Festuca rubra 5; Prunella vulgaris 5; Cerastium arvense 5; Scleranthus perennis 5; Gnaphalium uliginosum 6; Berteroa incana 6; Anchusa officinalis 6; Plantago major 6; Helichrysum arenarium 6; Cardaminopsis arenosa 7; Juncus bufonius 7; Saponaria officinalis 7. 
number of species per phytosociological relevé was 10.1. In these mesoregions, there was a lower share of differential species, in particular in the Żelechów Upland and Łuków Plain. The high constancy and cover of Anthoxanthum aristatum in the Siedlce Upland is noteworthy. The greatest number of patches with dominance of the species was found in the Kałuszyn Upland, where a sub-variant with the share of this species was distinguished. Patches dominated by Anthoxanthum aristatum were floristically poorer than the typical subvariants. In total, only 32 species were reported in these phytocoenoses, and the average number of species per relevé was 11.0 (Tab. 2).

The Arnoserido-Scleranthetum patches occupying the area of the Podlasie Gorge of Bug, i.e. the north-easternmost mesoregion, were substantially different in terms of their floristic composition. These communities exhibited relatively high species richness and the lowest share of differential species, as besides Scleranthus annuus only Veronica dillenii was found there. In turn, higher frequency and cover were reported for species characteristic of the alliance and order, in particular Anthemis arvensis and Centaurea cyanus. Characteristic species from the class Stellarietea mediae also represented a large proportion. Among these, the highest constancy and cover were reached by Spergula arvensis and Conyza canadensis, whereas Viola arvensis was noted frequently, but with lower cover rates. Among the accompanying species, Rumex acetosella exhibited the highest frequency and cover. Its cover was found to be the highest in the area of the Podlasie Gorge of Bug and Siedlce Upland (Tab. 2).

\section{Wet Arnoserido-Scleranthetum variant}

Phytocoenoses with the share of hygrophilous species were characterized by greater species richness than the typical patches (Tab. 3). Among them, the highest average number of species per relevé was found for the phytocoenoses with Illecebrum verticillatum noted exclusively in the Kałuszyn Upland (average number of species per relevé - 23.7). Scleranthus annuus constituted a lower proportion in patches containing hygrophilous species than in typical patches. It exhibited high frequency and cover only in the Siedlce Upland and Łuków Plain. A high share of Anthoxanthum aristatum was observed in these phytocoenoses of some mesoregions; the species reached considerably high cover rates in the area of the Węgrów Lowering and Żelechów Upland. The share of the other differential species was similar to that in the typical patches. The lowest proportion was found in phytocoenoses with Illecebrum verticillatum in the Kałuszyn Upland and in patches with Polygonum hydropiper in the Łuków Plain (Tab. 3).

The analysis of the share of hygrophilous species indicated the highest species richness in the phytocoenoses with Illecebrum verticillatum, where rare and endangered species, e.g. Illecebrum verticillatum, Radiola linoides, Centunculus minimus, Juncus capitatus, Hypericum humifusum and Peplis portula, were noted. The other analyzed phytocoenoses did not differ substantially in their hygrophilous species composition; some differences were only found in the occurrence frequency and cover rates of some species. No significant differences were reported in the occurrence of species characteristic of the alliance, order, and class.

\section{Systematic group value}

The analysis of the share of the characteristic and differential species carried out on the basis of the systematic group value indicated the highest value of the indicator for the phytocoenoses in the Kałuszyn Upland, Podlasie Gorge of Bug, Żelechów Upland, and Siedlce Upland (Tab. 4). However, this value was different when the share of Scleranthus annuus was not taken into account, in which case the greatest value of $D_{2}$ was noted for the communities with Anthoxanthum aristatum. The typical phytocoenoses in the Kałuszyn Upland were characterized by high values. The significant decrease in this value observed implies a considerable proportion of Scleranthus annuus in the communities of the Podlasie Gorge of Bug and Siedlce Upland. A general twofold decrease in this value was found in the phytocoenoses of the Podlasie Gorge of Bug and Łuków Plain. A slight change was noted in the patches with Anthoxanthum aristatum in the Kałuszyn Upland. Smaller differences were found for the wet phytocoenoses characterized by a lower share of Scleranthus annuus.

\section{Discussion}

Arnoserido-Scleranthetum is a sub-Atlantic association, which usually inhabits rye fields in the poorest habitats. Its patches develop on acidic soils, most frequently with a $\mathrm{pH}$ of 4.0-5.0 [17]. It has narrow ecological amplitude in relation to soil fertility and reaction, and considerable amplitude in relation to moisture content [17]. The highly specific habitat requirements determine its sensitivity to increasing intensification of agricultural production, such as liming and fertilization [18]. Another threat is posed by the abandonment and habitat transformation of the poorest low-productivity habitats [19]. Therefore, the association is threatened with extinction in many regions of Poland [2-7]. In Europe the situation is even worse due to the long-term farming intensification processes. Arnoseris minima is regarded as extinct in many regions of Germany (in Swabia and the Alp foothills); in Baden-Württemberg, Upper Rhine, and Black Forest, the species was endangered at the end of the 20th century [8]. Similarly, the species is threatened with extinction in the Czech Republic and Slovakia [20] as well as the Netherlands and France [21], while in Great Britain [11] and Switzerland the species is considered as extinct [21].

In Poland, the association has been reported from many regions; the greatest number of localities have been noted in the central part of the country $[17,19,22,23]$ where patches of the analyzed association are best developed in terms of both species composition and species richness. ArnoseridoScleranthetum phytocoenoses seem to be threatened to a greater extent in the south-western part of the country $[2,4,6]$ where the climatic conditions are more favorable than those prevailing in the central-eastern Poland [24-28]. This is related to the intensification of the anthropogenic impact in the western regions of the country and the high proportion of light soils and extensive farming in the east. The distribution of Arnoserido-Scleranthetum patches in the Południowopodlaska Lowland is associated with the presence of the poorest soils and the impact of the oceanic 
Tab. 3 Arnoserido-Scleranthetum (Chouard 1925) typicum variant form with hygrophilous species in the Południowopodlaska Lowland.

\begin{tabular}{|c|c|c|c|c|c|c|c|c|c|c|c|c|}
\hline \multirow{2}{*}{$\frac{\text { Mesoregion }}{\text { Number of records }}$} & \multicolumn{4}{|c|}{ Kałuszyn Upland } & \multicolumn{2}{|c|}{$\begin{array}{l}\text { Węgrów } \\
\text { Lowering }\end{array}$} & \multicolumn{2}{|c|}{$\begin{array}{l}\text { Żelechów } \\
\text { Upland }\end{array}$} & \multicolumn{2}{|c|}{ Siedlce Upland } & \multicolumn{2}{|c|}{ Luków Plain } \\
\hline & \multicolumn{2}{|c|}{10} & \multicolumn{2}{|c|}{20} & \multicolumn{2}{|c|}{10} & \multicolumn{2}{|c|}{10} & \multicolumn{2}{|c|}{20} & \multicolumn{2}{|c|}{12} \\
\hline Number of species & \multicolumn{2}{|c|}{63} & \multicolumn{2}{|c|}{70} & \multicolumn{2}{|c|}{57} & \multicolumn{2}{|c|}{59} & \multicolumn{2}{|c|}{55} & \multicolumn{2}{|c|}{68} \\
\hline $\begin{array}{l}\text { Mean number of weeds } \\
\text { species }\end{array}$ & \multicolumn{2}{|c|}{23.7} & \multicolumn{2}{|c|}{17.0} & \multicolumn{2}{|c|}{17.1} & \multicolumn{2}{|c|}{16.5} & \multicolumn{2}{|c|}{18.9} & \multicolumn{2}{|c|}{17.0} \\
\hline Subvariant & \multicolumn{2}{|c|}{$\begin{array}{c}\text { with Illecebrum } \\
\text { verticillatum }\end{array}$} & \multicolumn{2}{|c|}{$\begin{array}{l}\text { with Bidens } \\
\text { tripartita }\end{array}$} & \multicolumn{2}{|c|}{$\begin{array}{l}\text { with Juncus } \\
\text { bufonius }\end{array}$} & \multicolumn{2}{|c|}{$\begin{array}{l}\text { with Juncus } \\
\text { bufonius }\end{array}$} & \multicolumn{2}{|c|}{$\begin{array}{l}\text { with Juncus } \\
\text { bufonius }\end{array}$} & \multicolumn{2}{|c|}{$\begin{array}{c}\text { with } \\
\text { Polygonum } \\
\text { hydropiper }\end{array}$} \\
\hline \multirow[t]{2}{*}{ Column No. } & \multicolumn{2}{|c|}{1} & \multicolumn{2}{|c|}{2} & \multicolumn{2}{|c|}{3} & \multicolumn{2}{|c|}{4} & & & & \\
\hline & $S$ & D & $S$ & D & $S$ & D & $S$ & D & $S$ & $D$ & $S$ & D \\
\hline I. Ch. D. Arnoserido & lerant & & & & & & & & & & & \\
\hline Arnoseris minima & $\mathrm{V}$ & 505 & $\mathrm{~V}$ & 750 & $\mathrm{~V}$ & 540 & $\mathrm{~V}$ & 710 & $\mathrm{~V}$ & 753 & $\mathrm{~V}$ & 404 \\
\hline Anthoxanthum aristatum & II & 80 & IV & 350 & IV & 1260 & III & 1200 & & & I & 8 \\
\hline Scleranthus annuus & I & 20 & II & 90 & III & 90 & III & 120 & $\mathrm{~V}$ & 460 & $\mathrm{~V}$ & 321 \\
\hline Teesdalea nudicaulis & I & 20 & III & 310 & II & 120 & & & I & 30 & & \\
\hline Veronica dillenii & & & I & 5 & I & 60 & I & 10 & IV & 105 & I & 8 \\
\hline Holcus mollis & & & I & 123 & I & 10 & I & 60 & II & 45 & I & 8 \\
\hline Spergula vernalis & & & I & 30 & I & 10 & & & II & 50 & & \\
\hline
\end{tabular}

II. D. form with hygrophilous species

\begin{tabular}{|c|c|c|c|c|c|c|c|c|c|c|c|c|}
\hline Polygonum hydropiper & IV & 190 & $\mathrm{~V}$ & 240 & III & 345 & $\mathrm{~V}$ & 330 & III & 40 & $\mathrm{~V}$ & 150 \\
\hline Juncus bufonius & $\mathrm{V}$ & 700 & IV & 110 & $\mathrm{~V}$ & 550 & $\mathrm{~V}$ & 705 & $\mathrm{~V}$ & 1105 & II & 100 \\
\hline Gnaphalium uliginosum & III & 170 & II & 55 & II & 30 & IV & 150 & $\mathrm{~V}$ & 210 & IV & 67 \\
\hline Bidens tripartita & III & 60 & $\mathrm{~V}$ & 1043 & III & 90 & I & 10 & I & 10 & I & 8 \\
\hline Illecebrum verticillatum & $\mathrm{V}$ & 920 & & & & & & & & & & \\
\hline Hypericum humifusum & IV & 320 & II & 35 & II & 120 & I & 10 & & & II & 125 \\
\hline Radiola linoides & $\mathrm{V}$ & 575 & & & & & I & 10 & & & & \\
\hline Centunculus minimus & $\mathrm{V}$ & 130 & & & & & I & 10 & & & I & 42 \\
\hline Juncus capitatus & IV & 315 & II & 30 & $\mathrm{I}$ & 185 & I & 10 & & & I & 8 \\
\hline Equisetum sylvaticum & IV & 110 & II & 45 & I & 10 & I & 50 & & & II & 25 \\
\hline Peplis portula & IV & 230 & I & 15 & & & I & 60 & & & & \\
\hline Spergularia rubra & III & 60 & III & 45 & II & 30 & II & 70 & III & 45 & III & 83 \\
\hline Mentha arvensis & I & 10 & II & 25 & II & 110 & I & 10 & III & 50 & III & 221 \\
\hline Plantago pauciflora & III & 60 & I & 20 & & & I & 20 & $\mathrm{I}$ & 10 & & \\
\hline Sagina procumbens & II & 40 & I & 15 & II & 110 & I & 10 & & & I & 17 \\
\hline Stachys palustris & II & 40 & I & 20 & & & II & 30 & & & I & 17 \\
\hline Veronica serpyllifolia & II & 40 & & & & & II & 40 & & & I & 42 \\
\hline Myosurus minimus & II & 80 & I & 15 & I & 10 & & & I & 25 & & \\
\hline Gypsophila muralis & I & 20 & I & 15 & & & II & 30 & & & I & 50 \\
\hline Potentilla anserina & I & 10 & & & II & 80 & I & 10 & & & & \\
\hline Ranunculus repens & & & I & 10 & III & 100 & II & 40 & I & 5 & I & 8 \\
\hline Rorippa sylvestris & & & I & 5 & II & 30 & I & 20 & & & & \\
\hline Ranunculus sardous & & & & & $\mathrm{I}$ & 20 & II & 30 & & & & \\
\hline
\end{tabular}

III. Ch. Aperion spicae-venti, Centauretalia cyani

\begin{tabular}{|c|c|c|c|c|c|c|c|c|c|c|c|c|}
\hline Apera spica-venti & III & 345 & IV & 790 & III & 495 & IV & 900 & III & 115 & $\mathrm{~V}$ & 479 \\
\hline Anthemis arvensis & IV & 150 & III & 95 & III & 60 & IV & 110 & $\mathrm{~V}$ & 90 & III & 125 \\
\hline Centaurea cyanus & III & 60 & III & 75 & IV & 70 & IV & 190 & III & 40 & III & 42 \\
\hline Rhinanthus serotinus & I & 20 & I & 10 & I & 50 & II & 80 & & & & \\
\hline Vicia angustifolia & & & I & 5 & I & 10 & I & 10 & II & 25 & II & 33 \\
\hline Vicia villosa & & & & & & & III & 90 & & & I & 50 \\
\hline Hypochoeris glabra & & & & & & & I & 10 & II & 158 & & \\
\hline
\end{tabular}

IV. Ch. Stellarietea mediae

\begin{tabular}{lrrrrrrrrrrrrrr}
\hline Spergula arvensis & V & 130 & IV & 95 & IV & 70 & III & 90 & V & 95 & V & 200 \\
Viola arvensis & IV & 80 & III & 50 & III & 90 & II & 30 & V & 90 & II & 33
\end{tabular}


Tab. 3 (continued)

\begin{tabular}{|c|c|c|c|c|c|c|c|c|c|c|c|c|}
\hline \multirow[t]{2}{*}{ Column No. } & \multicolumn{2}{|c|}{1} & \multicolumn{2}{|c|}{2} & \multicolumn{2}{|c|}{3} & \multicolumn{2}{|c|}{4} & \multicolumn{2}{|c|}{5} & \multicolumn{2}{|c|}{6} \\
\hline & $S$ & $\mathbf{D}$ & $S$ & D & $S$ & D & $S$ & D & $S$ & D & $S$ & $\mathbf{D}$ \\
\hline Fallopia convolvulus & II & 40 & II & 35 & I & 10 & II & 40 & IV & 60 & I & 8 \\
\hline Chenopodium album & I & 20 & II & 40 & $\mathrm{I}$ & 20 & & & II & 30 & III & 50 \\
\hline Polygonum aviculare & II & 30 & I & 15 & $\mathrm{I}$ & 10 & I & 20 & II & 30 & II & 17 \\
\hline Stellaria media & I & 20 & I & 20 & II & 30 & I & 10 & I & 10 & & \\
\hline Setaria pumila & I & 10 & I & 5 & & & I & 20 & II & 100 & II & 67 \\
\hline Myosotis arvensis & I & 10 & I & 10 & & & $\mathrm{I}$ & 20 & II & 25 & I & 8 \\
\hline Digitaria ischaemum & I & 10 & I & 15 & & & I & 10 & II & 45 & I & 50 \\
\hline Convolvulus arvensis & I & 20 & I & 10 & & & & & & & II & 25 \\
\hline Raphanus raphanistrum & & & I & 10 & I & 10 & I & 10 & II & 30 & II & 33 \\
\hline Conyza canadensis & & & I & 5 & II & 30 & I & 20 & I & 10 & II & 58 \\
\hline Galeopsis tetrahit & & & & & $\mathrm{I}$ & 10 & & & I & 15 & III & 42 \\
\hline \multicolumn{13}{|c|}{ V. Accompanying species } \\
\hline Rumex acetosella & III & 470 & III & 95 & III & 100 & III & 140 & $\mathrm{~V}$ & 308 & $\mathrm{~V}$ & 396 \\
\hline Elymus repens & II & 30 & I & 15 & II & 30 & & & $\mathrm{~V}$ & 85 & III & 42 \\
\hline Equisetum arvense & I & 10 & II & 40 & II & 30 & I & 10 & III & 138 & II & 67 \\
\hline Achillea millefolium & I & 10 & II & 35 & III & 50 & I & 10 & & & II & 33 \\
\hline Cirsium arvense & II & 20 & I & 15 & & & & & & & I & 8 \\
\hline $\begin{array}{l}\text { Polygonum lapathifolium } \\
\text { subsp. lapathifolium }\end{array}$ & II & 20 & & & & & & & & & I & 8 \\
\hline Agrostis stolonifera & I & 10 & & & & & II & 205 & & & I & 42 \\
\hline Lysimachia numularia & II & 30 & & & & & & & & & & \\
\hline Trifolium repens & & & I & 5 & I & 20 & I & 10 & II & 30 & I & 8 \\
\hline Galeopsis ladanum & & & I & 10 & & & & & II & 25 & I & 8 \\
\hline Knautia arvensis & & & & & $\mathrm{I}$ & 10 & & & II & 25 & & \\
\hline $\begin{array}{l}\text { Sporadic species: II - Phragmites } \\
\text { hirsuta } 1,3,4,5,6 ; \text { Lithospermum } \\
\text { lapathifolium subsp. pallidum } 1,3 \text {, } \\
2 ; \text { Setaria viridis } 6 ; \mathrm{V} \text { - Veronica a } \\
\text { Taraxacum officinale } 2,5,6 ; \text { Holcu } \\
4,6 ; \text { Hypochoeris radicata } 5,6 ; \text { Or } \\
\text { Armoracia rusticana } 2 ; \text { Medicago } \\
\text { Cucubalus bacifer } 3 ; \text { Cerastium ser } \\
\text { canescens } 5 ; \text { Prunella vulgaris } 6 ; \text { E }\end{array}$ & $\begin{array}{l}\text { se } 2 ; A \\
\text { ctuca s } \\
\text { s } 1,2,3 \\
\text { atus } 3, \\
\text { us sati } \\
\text { na } 2 ; M \\
\text { andrum }\end{array}$ & $\begin{array}{l}\text { ola 1, 4; } \\
\text { 5, 6; Cer } \\
\text { Galeops } \\
\text { 5, 6; Dar } \\
\text { ago falc } \\
\text { Symphyt }\end{array}$ & $\begin{array}{l}\text { fida } 4, \\
\text { farota } \\
\text {; Poten } \\
\text { officina }\end{array}$ & $\begin{array}{l}\text { des } 1,2 \text {, } \\
\text { tellaria } \\
\text { lobium } \\
\text { rgentea }\end{array}$ & $\begin{array}{l}\text { ninea } 1 \\
\text { ttanum } \\
\text { erastin } \\
\text { tumm }\end{array}$ & $\begin{array}{l}\text { na 4, 6; } \\
\text { ium cicu } \\
\text { Plantago } \\
\text { Knautia } \\
\text { rvense } 2 \\
\text { a 4; Agro }\end{array}$ & $\begin{array}{l}\text { im } 1,2 \text {, } \\
\text { simulata } \\
\text { simum } \\
\text { giganted }\end{array}$ & 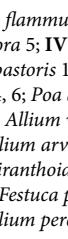 & $\begin{array}{l}\text { psanu } \\
\text { la } 1,3 \text {, } \\
\text { ale } 1,3 \\
2 ; \text { Poa } \\
\text { Myoso } \\
\text { nsis } 5 \text {; }\end{array}$ & $\begin{array}{l}\text { lustris } 4 \\
\text { nsis } 1,2 \text {, } \\
\text { nunis } 2 ; \\
\text { Polygon } \\
\text { phila ver } \\
\text { ensis } 2 ; 1 \\
\text { tricta } 3 \\
\text { lis acetos }\end{array}$ & $\begin{array}{l}\text { - Vicia } \\
\text { Polyg } \\
\text { ium pu } \\
\text { oersica } \\
\text { 5; Ave } \\
\text { ia vul } \\
\text { acium } \\
5 ; \text { Cory }\end{array}$ & $\begin{array}{l}n \\
\text { reum } \\
\text { strigosa } \\
2 ; \\
\text { sella 3; } \\
\text { horus }\end{array}$ \\
\hline
\end{tabular}

$S$ - constancy; D - cover coefficient.

Tab. 4 Systematic group value (D) for Arnoserido-Scleranthetum phytocoenoses in the mesoregions of the Południowopodlaska Lowland.

\begin{tabular}{|c|c|c|c|c|c|c|c|}
\hline Mesoregion & Kałuszy & Upland & $\begin{array}{l}\text { Węgrów } \\
\text { Lowering }\end{array}$ & $\begin{array}{l}\text { Żelechów } \\
\text { Upland }\end{array}$ & Siedlce Upland & Luków Plain & $\begin{array}{c}\text { Podlasie } \\
\text { Gorge of Bug }\end{array}$ \\
\hline Subvariant & typical & $\begin{array}{c}\text { with } \\
\text { Anthoxanthum } \\
\text { aristatum }\end{array}$ & typical & typical & typical & typical & typical \\
\hline$D_{1}(\%)$ & 14.8 & 19.3 & 9.1 & 11.5 & 11.2 & 5.9 & 12.9 \\
\hline$D_{2}(\%)$ & 8.4 & 14.4 & 4.0 & 5.3 & 5.8 & 2.0 & 4.6 \\
\hline Subvariant & $\begin{array}{c}\text { with } \\
\text { Illecebrum } \\
\text { verticillatum }\end{array}$ & $\begin{array}{l}\text { with Bidens } \\
\text { tripartita }\end{array}$ & $\begin{array}{c}\text { with Juncus } \\
\text { bufonius }\end{array}$ & $\begin{array}{l}\text { with Juncus } \\
\text { bufonius }\end{array}$ & $\begin{array}{c}\text { with Juncus } \\
\text { bufonius }\end{array}$ & $\begin{array}{l}\text { with } \\
\text { Polygonum } \\
\text { hydropiper }\end{array}$ & - \\
\hline$D_{1}(\%)$ & 3.2 & 6.8 & 7.1 & 6.2 & 9.7 & 4.9 & - \\
\hline$D_{2}(\%)$ & 2.4 & 5.6 & 4.9 & 3.8 & 5.2 & 1.8 & - \\
\hline
\end{tabular}


climate. Therefore, the highest density of the patches was observed in the localities of the Kałuszyn Upland, i.e. the south-westernmost mesoregion, whereas the lowest density was noted in the Podlasie Gorge of Bug area, which is the north-easternmost region.

Arnoserido-Scleranthetum shows no regional variation, although impoverishment of the floristic composition can be observed towards the north east as indicated by the gradual disappearance of the differential species [28-31]. In the Południowopodlaska Lowland, except for the area of the Podlasie Gorge of Bug, Arnoserido-Scleranthetum phytocoenoses are well developed and they comprise all differential species. These communities do not differ in their species composition from those described in central Poland [22,23]. Impoverished patches with a low share of differential species, with total absence of Teesdalea nudicaulis and Anthoxanthum aristatum, were only noted in the peripheries of the occurrence range. Until recently, these species have not been noted in the patches of the analyzed association in the area of the Podlasie Gorge of Bug despite the considerable spread of Anthoxanthum aristatum across the Południowopodlaska Lowland [32]. The mass occurrence of the species in Arnoserido-Scleranthetum patches leads to changes in the structure and species composition of the analyzed phytocoenoses. The dominance of Anthoxanthum aristatum in the analyzed patches by competitive interaction results in impoverishment of the phytocoenoses, affecting adversely their biodiversity. A similar degenerative impact of this species has also been observed in other mesoregions of the country [33-35].

In Germany, where there are disastrous changes in the occurrence of some archaeophytes, including Arnoseris minima $[13,36]$, field fallowing accompanied by compensation for farmers is proposed with the aim of protection under agro-environmental schemes as well as the establishment of protected sites, i.e. field belts cultivated in the traditional way without application of pesticides [18]. In this context, weed diaspore seeding is a special protection method $[12,37,38]$ for impoverished poor sandy fields.

Currently, there are no indications for special protection of Arnoserido-Scleranthetum patches in the Południowopodlaska Lowland, since they constitute common phytocoenoses in

\section{Acknowledgments}

Research supported by the Ministry of Science and Higher Education of Poland as part of the statutory activities of the Department of Agricultural Ecology, Siedlce University of Natural Sciences and Humanities.

\section{Authors' contributions}

The following declarations about authors' contributions to the research have been made: concept of the study: ZR, TS, JS; field work: ZR, TS, JS; data analyses: ZR, TS, JS; writing of the manuscript: ZR.

\section{Competing interests}

No competing interests have been declared.

\section{References}

1. Matuszkiewicz W. Przewodnik do oznaczania zbiorowisk roślinnych Polski. Warszawa: Państwowe Wydawnictwo Naukowe; 2007.

2. Babczyńska-Sendek B, Bula R, Cabała S, Celiński F, Hereźniak J, this area. Only patches of Arnoserido-Scleranthetum with Illecebrum verticillatum are threatened with extinction due to changes in the crop structure and increased nitrogen fertilization [39-41]. Their composition comprises a large group of endangered sub-Atlantic species of the class IsoëtoNanojuncetea, e.g. Illecebrum verticillatum, Radiola linoides, Hypericum humifusum, Juncus capitatus, Peplis portula, Centunculus minimus, and Gnaphalium luteo-album. Similar phytocoenoses with the species mentioned above were reported by Warcholińska $[42,43]$. Their presence depends on the low content of nutrients as well as humidity and light conditions [43]. For that reason, the intensification of production (melioration, fertilization, large share of arable crops) is currently a major threat to these communities. Species of the class Isoëto-Nanojuncetea belong to the most endangered in Central Europe $[39,40,44,45]$. Therefore, effective methods of their protection should be applied in Poland [41].

\section{Conclusions}

(i) Arnoserido-Scleranthetum phytocoenoses were noted in all the analyzed mesoregions. The association occurred with the highest frequency in the western part of the Południowopodlaska Lowland.

(ii) The distribution of Arnoserido-Scleranthetum phytocoenoses depends on the presence of trophically poor light acidic soils and climatic conditions. The cooler climate at the northern-east end of the macroregion limits the occurrence of the analyzed association.

(iii) Impoverishment of the composition and structure of the analyzed association towards the north east was found.

(iv) The increasing frequency of Anthoxanthum aristatum occurrence led to impoverishment of the analyzed phytocoenoses, as well.

(v) In order to protect the biodiversity of ArnoseridoScleranthetum phytocoenoses, especially those with the participation of the Isoëto-Nanojuncetea species, it is necessary to provide additional payments supporting traditional farming practices under agroenvironmental programs.

Kuźniewski E, et al. Czerwona lista zbiorowisk roślinnych Górnego Śląska. Centrum Dziedzictwa Przyrody Górnego Śląska. Raporty Opinie. 1997;2:38-68.

3. Korniak T. Ginące i zagrożone gatunki flory segetalnej w północnowschodniej Polsce. Acta Univ Lodz Folia Bot. 1998;13:43-50.

4. Anioł-Kwiatkowska J. Ginące i zagrożone gatunki segetalne na Wale Trzebnickim. Acta Univ Lodz Folia Bot. 1998;13:169-176.

5. Trąba C, Ziemińska-Smyk M. Stan gatunków chwastów segetalnych uważanych za zagrożone w otulinie Roztoczańskiego Parku Narodowego. Acta Univ Lodz Folia Bot. 1998;13:265-272.

6. Nowak A, Nowak S, Spałek K. Red list of vascular plants of Opole province - 2008. Opole Scientific Society, Nature Journal. 2008;41:141-158.

7. Bomanowska A. Threat to arable weeds in Poland in the light of national and regional red lists. Plant Breeding and Seed Science. 2010;61:55-74. http://dx.doi.org/10.2478/v10129-010-0013-7

8. Breunig T, Demuth S. Rote Liste der Farn - und Samenpflanzen BadenWürttembergs. Karlsruhe: Landesanstalt für Umweltschutz; 1999. 
9. Kubát K, Kaplan Z. Arnoseris minima Schweigg. et Koerte in the Czech Republic. Severočes Př́r Litoměřice. 2001;32:29-36.

10. Prasse R, Ristow M, Klemm G, Machatzi B, Raus T, Scholz H, et al. Liste der wildwachsenden Gefäßpflanzen des Landes Berlin mit Roter Liste. Hrsg.: Senatsverwaltung für Stadtentwicklung / Der Landesbeauftragte für Naturschutz und Landschaftspflege. Berlin: Kulturbuch-Verlag; 2001.

11. Preston CD, Pearman DA, Dines TD. An atlas of the vascular plants of Britain, Ireland. The Isle of Man and the Channel Islands. Oxford: Oxford University Press; 2002.

12. Meyer S, Wesche K, Leuschner C, van Elsen T, Metzner J. A new conservation strategy for arable plant vegetation in Germany - the project "100 fields for biodiversity". Plant Breeding and Seed Science. 2010;61:25-34. http://dx.doi.org/10.2478/v10129-010-0009-3

13. Meyer S, Wesche K, Krause B, Leuschner C. Dramatic losses of specialist arable plants in central Germany since the 1950s/60s - a cross-regional analysis. Divers Distrib. 2013;19:1175-1187. http:// dx.doi.org/10.1111/ddi.12102

14. Pawłowski B. Skład i budowa zbiorowisk roślinnych oraz metody ich badania. In: Szafer W, Zarzycki K, editors. Szata roślinna Polski. Warszawa: PWN; 1972. p. 237-268.

15. Mirek Z, Piękoś-Mirkowa H, Zając A, Zając M, editors. Flowering plants and pteridophytes of Poland - a checklist. Kraków: W. Szafer Institute of Botany, Polish Academy of Sciences; 2002. (Biodiversity of Poland; vol 1).

16. Dzwonko Z. Przewodnik do badań fitosocjologicznych. Poznań: Sorus; 2008. p. 169-176.

17. Warcholińska U. Arnoserido-Scleranthetum annui (Chouard 1925) R. Tx. 1937 corr. Matuszkiewicz 1981 em. Warcholińska 1990 in Poland. Thaiszia. 1995;5:81-96.

18. Berger G, Kaechele H, Pfeffer H. The greening of the European common agricultural policy by linking the European-wide obligation of set-aside with voluntary agri-environmental measures on a regional scale. Environ Sci Policy. 2006;9(6):509-524. http://dx.doi. org/10.1016/j.envsci.2006.05.006

19. Siciński JT. Agrofitocenozy dorzecza środkowej Warty i Bzury stan, dynamika i zagrożenia. Łódź: Wydawnictwo Uniwersytetu Łódzkiego; 2003.

20. Lososová Z, Chytrý M, Cimalová Š, Otýpková Z, Pyšek P, Tichý L. Classification of weed vegetation of arable land in the Czech Republic and Slovakia. Folia Geobot. 2006;41:259-273. http://dx.doi. org/10.1007/BF02904941

21. Welk E. Arealkundliche Analyse und Bewertung der Schutzrelevanz seltener und gefährdeter Gefäßpflanzen Deutschlands [PhD thesis]. Halle: Martin-Luther-Universität; 2001.

22. Warcholińska AU. Flora i roślinność segetalna Sulejowskiego Parku Krajobrazowego. Cz. II. Roślinność segetalna. Acta Agrobot. 1997;50(1-2):181-202. http://dx.doi.org/10.5586/aa.1997.018

23. Warcholińska AU. Flora i roślinność segetalna Bolimowskiego Parku Krajobrazowego. Cz. II. Roślinność segetalna. Acta Agrobot. 1997;50(1-2):141-161. http://dx.doi.org/10.5586/aa.1997.016

24. Skrzyczyńska J. Studia nad florą i zbiorowiskami segetalnymi Wysoczyzny Siedleckiej. Wyd. WSR-P w Siedlcach. Rozp. 1994; 39: 5-145.

25. Skrzyczyńska J, Skrajna T. Zbiorowiska polne Wysoczyzny Kałuszyńskiej. Cz. I. Zespoły zbożowe. Fragm Agron. 2004;4(84):33-43.

26. Skrzyczyńska J, Rzymowska Z. Zbiorowiska roślinne pól uprawnych Podlaskiego Przełomu Bugu. Cz. I. Zespoły zbożowe. Acta Agrobot. 2005;58(1):255-290. http://dx.doi.org/10.5586/aa.2005.028

27. Skrajna T, Skrzyczyńska J, Ługowska M. Segetal communities of cereal crops of the Mazowiecki Landscape Park. Acta Agrobot. 2009;62(1):171-186. http://dx.doi.org/10.5586/aa.2009.020

28. Rzymowska Z, Skrajna T. Associations and communities of cereal crops of the Łuków Plain. Part I. Light soil associations. Acta Agrobot. 2011;62(1):171-186. http://dx.doi.org/10.5586/aa.2011.066

29. Anioł-Kwiatkowska J. Zbiorowiska segetalne Wału Trzebnickiego. Florystyczno-ekologiczne studium porównawcze. Wrocław:
Wydawnictwo Uniwersytetu Wrocławskiego; 1990. (Acta Universitatis Wratislaviensis. Prace botaniczne; vol 46).

30. Rzymowska Z. Współczesne zmiany we florze i zbiorowiskach segetalnych Podlaskiego Przełomu Bugu. Siedlce: Wydawnictwo Uniwersytetu Przyrodniczo-Humanistycznego w Siedlcach; 2013. (Rozprawa naukowa; vol 124).

31. Polakowski B, Korniak T, Hołdyński C. Zespół Arnoserido-Scleranthetum (Chouard 1925) Tx. 1937 w północno-wschodniej części Polski. Zesz Nauk WSRP Siedlce Ser Rolnictwo. 1989;20:196-204.

32. Skrzyczyńska J, Skrajna T, Rzymowska Z. Ekspansja Anthoxanthum aristatum Boiss. w uprawach rolniczych na Nizinie Południowopodlaskiej. Fragm Agron. 2010;27(2):135-144.

33. Szmeja K. Anthoxanthum aristatum Boiss. - ekspansywny chwast pól uprawnych Równiny Charzykowskiej. Zesz Nauk ATR Bydgoszcz Ser Rolnictwo. 1996;196(38):193-196.

34. Warcholińska AU, Siciński JT. Ekspansja Anthoxanthum aristatum Boiss. w środkowej Polsce. Zesz Nauk ATR Bydgoszcz Ser Rolnictwo. 1996;196(38):183-191.

35. Kozak M. Zbiorowiska segetalne gminy Rudniki (województwo opolskie). Fragm Flor Geobot Polonica. 2002;9:219-272.

36. Storkey J, Meyer S, Still KS, Leuschner C. The impact of agricultural intensification and land-use change on the European arable flora. Proc Biol Sci. 2012;279:1421-1429. http://dx.doi.org/10.1098/ rspb.2011.1686

37. Meyer S, Wesche K, Leuschner C, van Elsen T, Metzner J. Schutzbemühungen für die Segetalflora in Deutschland - Das Projekt "100 Äcker für die Vielfalt” Treffpunkt Biologische Vielfalt 9. Bonn: Hrsg. Bundesamt für Naturschutz; 2010.

38. Meyer S, Wesche K, Leuschner C, van Elsen T, Metzner J. A new consevation strategy for arable plant vegetation in Germany - the project "100 fields for biodiversity". Plant Breeding and Seed Science. 2010;61:25-34. http://dx.doi.org/10.2478/v10129-010-0009-3

39. Skrajna T, Kubicka H, Rzymowska Z. Illecebrum verticillatum L. endangered species in agrocenoses of eastern Poland: assessment of ecological and genetic indicators for protection goals. Pol J Ecol. 2012;60(3):577-589.

40. Skrajna T. The effect of farming method on the dynamics of communities from the alliance Radiolion linoidis (Rias Goday 1961) Pietach 1965 in Kałuszyn Upland agrocenoses. Acta Agrobot. 2014;67(1):85-98. http://dx.doi.org/10.5586/aa.2014.002

41. Skrajna T, Gozdowski D, Ługowska M. The transformations of field communities with Illecebrum verticillatum L. (Cariophyllaceae) on the borderlands of its European range (central-eastern Poland). Pol J Ecol. 2014;62(1):3-15. http://dx.doi.org/10.3161/104.062.0102

42. Warcholińska AU. Fitocenozy polne z udziałem Illecebrum verticillatum L. i ich wartość diagnostyczna. Fragm Florist. 1981;27:622-625.

43. Warcholińska AU. Klasyfikacja numeryczna zbiorowisk segetalnych Wzniesień Łódzkich. Łódź: Wydawnictwo Uniwersytetu Łódzkiego; 1990.

44. Altenfelder S, Raabe U, Albrecht H. Effects of water regime and agricultural land use on diversity and species composition of vascular plants inhabiting temporary ponds in northeastern Germany. Tuexenia. 2015;34:145-162. http://dx.doi.org/10.14471/2014.34.013

45. Albrecht H, Prestele J, Altenfelder S, Wiesinger K, Kollmann J. New approaches to the conservation of rare arable plants in Germany. 26. Deutsche Arbeitsbesprechung über Fragen der Unkrautbiologie und -bekämpfung, 11.-13. März 2014 in Bandenburg. Julius-Kühn-Archiv 2014;443:180-189. http://dx.doi.org/10.5073/jka.2014.443.021

\section{Występowanie i zróżnicowanie Arnoserido- Scleranthetum (Chouard 1925) na Nizinie Południowopodlaskiej}

\section{Streszczenie}

W pracy przedstawiono analizę fitocenoz Arnoserido-Scleranthetum na wschodnich i północno-wschodnich krańcach zasięgu. Praca obejmuje 
wyniki badań terenowych prowadzonych na obszarze Niziny Południowopolskiej w latach 1990-2010. Polegały one na wykonaniu zdjęć fitosocjologicznych metodą Braun-Blanqueta. Najliczniej stanowiska analizowanego zespołu notowano w mezoregionach położonych w południowo-zachodniej części Niziny Południowopodlaskiej: Wysoczyzna Kałuszyńska, Obniżenie Węgrowskie, Wysoczyzna Żelechowska i południowo-zachodnia część Równiny Łukowskiej oraz południowa Wysoczyzny Siedleckiej. Znacznie rzadziej spotykano płaty tego zespołu we wschodniej i północno wschodniej części Niziny Południowopodlaskiej a zwłaszcza na obszarze Podlaskiego Przełomu Bugu. Notowano tam jedynie wyspowe stanowiska fitocenoz Arnoserido-Scleranthetum. We wszystkich mezoregionach $\mathrm{z}$ wyjątkiem Podlaskiego Przełomu Bugu płaty analizowanego zespołu wykazywały wewnętrzną zmienność odzwierciedlającą zróżnicowanie warunków siedliskowych pod względem uwilgotnienia. Znalazło to wyraz $\mathrm{w}$ występowaniu $\mathrm{w}$ analizowanych fitocenozach gatunków higrofilnych. Wśród nich notowano rzadkie, ginących gatunki, takie jak: Illecebrum verticillatum, Juncus capitatus, Radiola linoides, Hypericum humifusum. Zbiorowiska Arnoserido-Scleranthetum z Illecebrum verticillatum należą do zagrożonych wyginięciem w Polsce i w Europie. Większość płatów Arnoserido-Scleranthetum na obszarze Niziny Południowopodlaskiej jest dobrze wykształcona i nie różni się składem gatunkowym od fitocenoz z centralnej Polski. Szczególną uwagę zwracają fitocenozy Arnoserido-Scleranthetum $\mathrm{z}$ dominacją Anthoxanthum aristatum, jako wyraz zmian degeneracyjnych spowodowanych masowym występowaniem tego ekspansywnego gatunku. Zbiorowiska takie notowano przede wszystkim Wysoczyźnie Kałuszyńskiej, Wysoczyźnie Siedleckiej i Wysoczyźnie Żelechowskiej. 